\title{
Kinetics of $\mathrm{GABA}_{\mathrm{B}}$ Receptor-Mediated Inhibition of Calcium Currents and Excitatory Synaptic Transmission in Hippocampal Neurons In Vitro
}

\author{
F. W. Pfrieger, K. Gottmann, and H. D. Lux \\ Max-Planck-Institute for Psychiatry \\ Department of Neurophysiology \\ Am Klopferspitz 18A \\ D-82152 Planegg-Martinsried \\ Germany
}

\section{Summary}

The time courses of the $\gamma$-aminobutyric acid type $B$ $\left(G A B A_{B}\right)$ receptor-mediated inhibition of excitatory synaptic transmission and of action potential-evoked calcium currents were studied in hippocampal neurons in vitro with step-like changes of a saturating baclofen concentration. Inhibition mediated by postsynaptic $\mathrm{GABA}_{\mathrm{B}}$ receptors was excluded pharmacologically. Both presynaptic inhibition and reduction of calcium currents developed and declined exponentially with similar time constants of about 0.2 and $3 \mathrm{~s}$, respectively. The close correlation of the time courses indicates that fast, $G$ protein-mediated depression of voltage-gated calcium channels and thus direct reduction of the presynaptic calcium influx may contribute to the $\mathrm{GABA}_{B}$ receptorinduced inhibition of excitatory synaptic transmission in hippocampal neurons in vitro.

\section{Introduction}

Activation of the $G$ protein-coupled subtype of $\gamma$-aminobutyric acid type $B\left(\mathrm{GABA}_{B}\right)$ receptors (for reviews see Bowery, 1989, 1993; Sivilotti and Nistri, 1991) inhibits excitatory synaptic transmission between hippocampal neurons (Scholz and Miller, 1991; Yoon and Rothman, 1991; Solis and Nicoll, 1992; Thompson and Gähwiler, 1992; for earlier publications see Nicoll et al., 1990). Postsynaptically, the $\mathrm{CABA}_{B}$ receptor-induced inhibition is due to a potassium-dependent, slow inhibitory postsynaptic potential (for reviews see Nicoll et al., 1990; Crunelli and Leresche, 1991; Sivilotti and Nistri, 1991). The presynaptic mechanisms of this short-term modulation, however, are still debated (Miller, 1990; Gage, 1992; Thompson et al., 1993). By coupling to $G$ proteins (Morishita et al., 1990), GABA receptors affect a set of effectors including ion channels and cytoplasmic enzymes (for reviews see Bowery, 1989, 1993; Nicoll et al., 1990; Sivilotti and Nistri, 1991), each of which could contribute to presynaptic inhibition, as suggested by previous studies (Holz et al., 1989; Travagli et al., 1991; Thompson and Gähwiler, 1992). The $G A B A_{B}$ receptor-induced depression of voltage-gated calcium channels (for reviews see Carbone and Swandulla, 1989; Schultz et al., 1990; Anwyl, 1991; Scott et al., 1991; Bowery et al., 1993) would effectively inhibit transmitter release by reducing the presynaptic calcium influx. In hippocampal neurons, this mechanism of presynaptic inhibition has been sug- gested by Scholz and Miller (1991), who demonstrated $\mathrm{GABA}_{\mathrm{B}}$ receptor-induced inhibition of both voltageactivated calcium currents and evoked excitatory postsynaptic currents (EPSCs) in vitro. Evidently, this requires that the $G A B A_{B}$ receptor-induced reduction of voltage-activated calcium currents develops with identical kinetics as the presynaptic inhibition. To test whether this important, but previously not considered, condition was fullfilled, we resolved the time courses of the $\mathrm{GABA}_{B}$ receptor-induced inhibition of evoked EPSCs by means of superfusion techniques that allowed step-like changes of the baclofen concentration at cultured synapses. The calcium transients that trigger transmitter release from presynaptic terminals cannot be easily measured. Hence, we studied the time course of the $G A B A_{B}$ receptor-induced inhibition of whole-cell voltage-activated calcium currents. To investigate their modulation under physiological conditions, we imitated the natural stimulus of presynaptic calcium influx and used an action potential-like voltage command to evoke calcium currents, which lasted about $3 \mathrm{~ms}$. Previously, neurotransmitter-induced inhibition of voltage-gated calcium channels was analyzed after depolarization of neurons for tens to hundreds of milliseconds, which had been shown to affect the $\mathrm{GABA}_{B}$ receptor-induced inhibition (Grassi and Lux, 1989). Our study revealed that the $\mathrm{GABA}_{B}$ receptor-induced inhibition of excitatory synaptic transmission and action potential-evoked calcium currents developed with closely matching time courses. Kinetic analysis thus supports the hypothesis that direct depression of presynaptic, voltage-gated calcium channels may contribute to presynaptic inhibition in hippocampal neurons in vitro.

\section{Results}

\section{Baclofen-Induced Inhibition of Evoked EPSCs}

To study excitatory synaptic transmission in cultured hippocampal neurons, EPSCs were evoked by extracellular stimulation of presynaptic neurons in the presence of the $\gamma$-aminobutyric acid type A receptor antagonist bicuculline methchloride $(50 \mu \mathrm{M})$. Postsynaptic $\mathrm{GABA}_{B}$ receptor-induced inhibition was suppressed by adding the lidocaine derivative QX-314, which blocks $\mathrm{GABA}_{\mathrm{B}}$ receptor-induced potassium currents (Nathan et al., 1990; Andrade, 1991; Otis et al., 1993), intracellularly to postsynaptic neurons (Lambert and Wilson, 1993). This drug also suppressed voltage-activated sodium currents (see Experimental Procedures). Latencies of monosynaptic EPSCs ( $<5 \mathrm{~ms})$ ranged from 1.4 to $4.5 \mathrm{~ms}$ (mean, $2.8 \pm 0.8 \mathrm{~ms} ; \mathrm{n}=$ 46). Peak amplitudes of evoked EPSCs, which reversed at $0 \mathrm{mV}(\mathrm{n}=6$; Figure $1 \mathrm{~A})$, ranged from -20 to -922 $\mathrm{pA}$ at $-70 \mathrm{mV}$ holding potential (mean, $284 \pm 230 \mathrm{pA}$; $\mathrm{n}=121)$ and were reversibly blocked by 6,7 . 
A

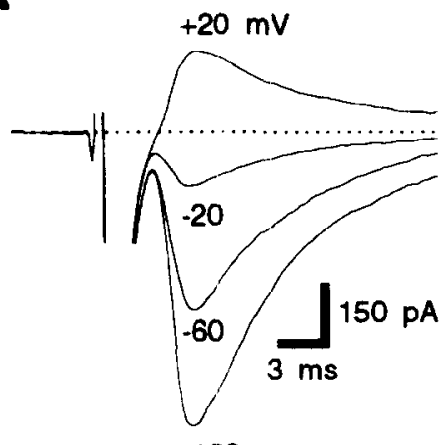

$-100$

B

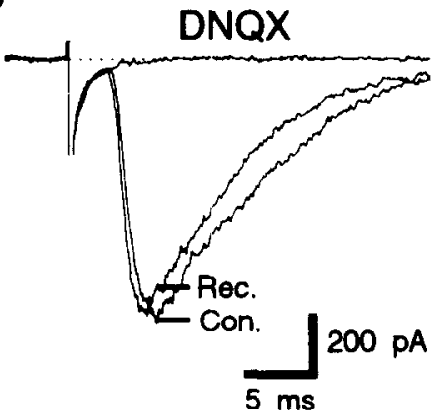

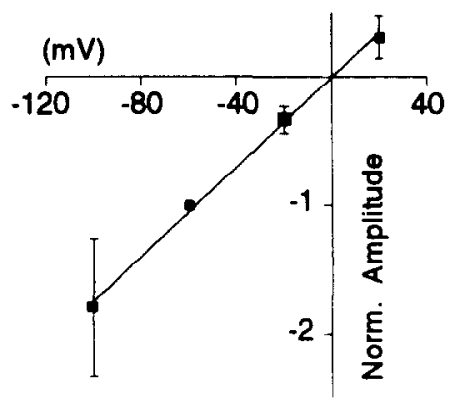

C

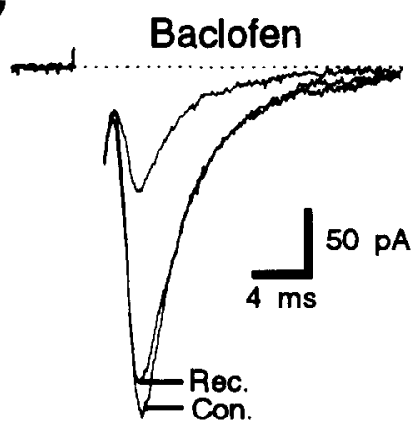

Figure 1. Characterization of Extracellularly Evoked EPSCs

(A) EPSCs, evoked by extracellular stimulation in the presence of bicuculline methchloride $(50 \mu \mathrm{M})$ extracellularly, reversed at $0 \mathrm{mV}$ holding potential indicating the increase of a nonselective cationic conductance. The current-voltage curve was averaged from normalized EPSC peak amplitudes ( $n=6$; error bars indicate $S D$ ). (B) EPSCs, evoked at $-70 \mathrm{mV}$ holding potential, were reversibly blocked by the selective antagonist 6,7-dinitroquinoxaline-2,3-dione (DNQX; $10 \mu \mathrm{M}$ ), indicating that postsynaptic non-NMDA glutamate receptors mediated the response.

(C) Superfusion of synapses with baclofen $(10 \mu \mathrm{M})$, a selective $\mathrm{GABA}_{B}$ receptor agonist, reversibly inhibited evoked EPSCs. The inhibition was presynaptic, as the lidocaine derivative QX-314 $(20 \mathrm{mM})$ blocked postsynaptic, $\mathrm{GABA}_{\mathrm{B}}$ receptor-induced potassium currents. dinitroquinoxaline-2,3-dione (DNQX; $10 \mu \mathrm{M} ; 93 \% \pm$ $5 \%$ inhibition; $n=7$; Figure $1 \mathrm{~B}$ ), indicating that extracellularly evoked EPSCs were mediated by non-NMDA glutamate receptors. NMDA receptor-mediated components of EPSCs were blocked by extracellular magnesium (2 mM).

In 16 out of 17 synapses, application of the selective $\mathrm{GABA}_{\mathrm{B}}$ receptor agonist $\mathrm{R}(+)$-baclofen (baclofen; 10 $\mu M)$ reversibly inhibited peak amplitudes of evoked EPSCs by $44 \%-81 \%$ (mean, $67 \% \pm 10 \%$; Figure $1 \mathrm{C}$ ). The presynaptic inhibition was mediated by $G A B A_{B}$ receptors, as it was suppressed by the selective receptor antagonist CGP $35348(500 \mu \mathrm{M}$; mean of inhibition, $6 \% \pm 4 \% ; n=5$; Olpe et al., 1990), in line with previous reports (Solis and Nicoll, 1992; Thompson and Gähwiler, 1992). The involvement of $G$ proteins in the $\mathrm{GABA}_{B}$ receptor-induced inhibition was tested by pretreating cultures with pertussis toxin (PTX; $500 \mathrm{ng}$ / $\mathrm{ml}$ for at least $24 \mathrm{hr}$ ), which inactivates $\mathrm{G}_{\alpha i}$ and $\mathrm{G}_{\alpha o}$ subunits (Ui, 1984; Milligan, 1988). In PTX-treated cultures, the baclofen-induced inhibition of EPSCs was abolished (mean of inhibition, $3 \% \pm 4 \% ; n=6$ ). Thus, excitatory synaptic transmission between cultured hippocampal neurons was inhibited by $\mathrm{GABA}_{B}$ receptor-activated, PTX-sensitive $G$ proteins as reported previously (Huston et al., 1990; Scholz and Miller, 1991; Yoon and Rothman, 1991). In other hippocampal preparations, however, the $\mathrm{GABA}_{B}$ receptor-induced inhibition of excitatory synaptic transmission persisted throughout PTX treatment (Dutar and Nicoll, 1988; Colmers and Pittman, 1989; Thompson and Gäh- wiler, 1992). These discrepancies might be explained by cell type-specific differences in the activated $G$ proteins or by the less effective PTX application in vivo compared with in vitro (Nicoll et al., 1990; Scott et al., 1991).

\section{Kinetics of the GABA $\mathrm{B}_{\mathrm{B}}$ Receptor-Mediated, Presynaptic Inhibition of Evoked EPSCs}

The onset of the $G A B A_{B}$ receptor-mediated inhibition of evoked EPSCs was studied with rapid application of a saturating baclofen concentration $(50 \mu \mathrm{M})$ to cultured synapses (see Experimental Procedures). Steplike application was achieved by the pressure-driven extension of a laminar stream of agonist-containing solution positioned beneath the stimulated synapse, which was localized by the tip of the patch pipette delivering the extracellular stimulus (Figure 2A). The method allowed detection of the onset of inhibition at $50 \mathrm{~ms}$ (see Experimental Procedures). In the $10 \mathrm{syn}$ apses analyzed, rapid agonist application was proved with cadmium $(50 \mu \mathrm{M})$, which instantly inhibits synaptic transmission by blocking presynaptic calcium currents (Pfrieger et al., 1992; Figure 3A). Figure 3B shows the time-resolved inhibition of excitatory synaptic transmission by cadmium and baclofen. The time courses of the presynaptic inhibition, induced by cadmium and baclofen, clearly differed. Cadmium suppressed EPSCs rapidly by a direct block of presynaptic calcium channels, whereas baclofen activated a multistep signal transduction pathway involving $G A B A_{B}$ receptors and $\mathrm{PTX}$-sensitive $G$ proteins. The $\mathrm{GABA}_{B}$ 


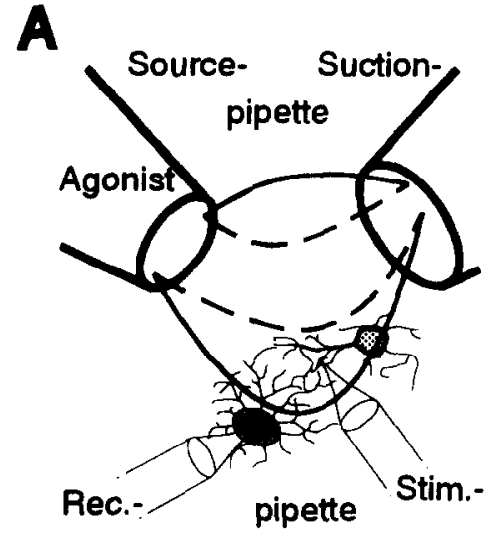

B
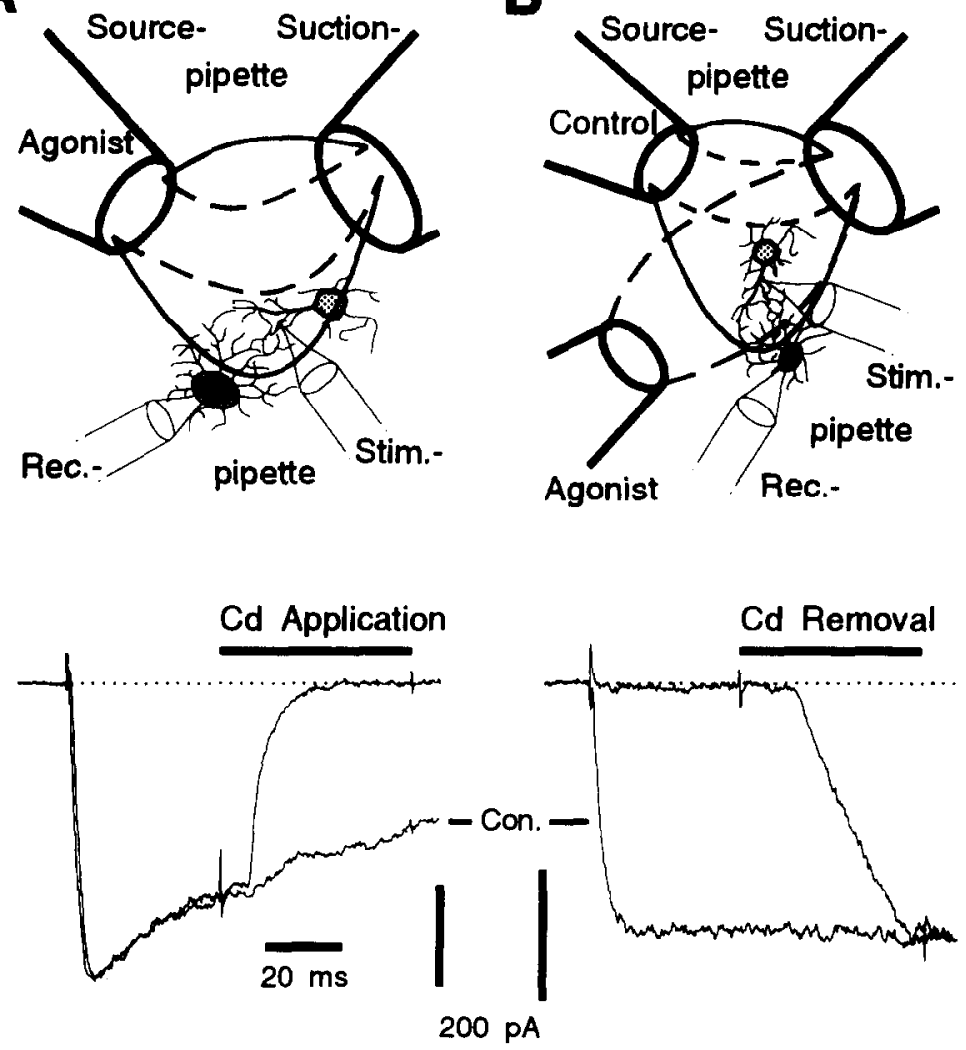

Figure 2. Superfusion Techniques for Rapid Changes of Agonist Concentrations at Cultured Neurons and Synapses

(A) Technique for fast agonist application to extracellularly stimulated synapses: A laminar stream of agonist-containing solu. tion formed between two oppositely placed glass pipettes if positive and negative hydrostatic pressure was applied to the source and the suction pipette, respectively (top; broken line). A valve-controlled pressure increase in the source pipette extended the stream, thus superfusing the stimulated region (top; solid line). The speed of the concentration change was tested with the cadmium-induced block of HVA calcium currents elicited by voltage steps from -70 to $0 \mathrm{mV}$. In small neurons without neurites, fast application of cadmium $(100 \mu \mathrm{M})$ blocked the HVA calcium current within maximally $50 \mathrm{~ms}$ (bottom). (B) Technique for fast removal of the agonist from a stimulated synapse: Under control conditions, the synapse was steadily superfused with the agonist (top; broken line). The superfusion was terminated rapidly by application of negative pressure to the agonist-containing source pipette, and the agonist was quickly displaced by the simultaneous extension of a nearby stream of agonist-free control solution (top; solid line). The block of the HVA calcium current by cadmium $(100 \mu \mathrm{M})$ was alleviated within $50 \mathrm{~ms}$ in a small neuron without neurites (bottom). receptor-induced inhibition rose with a delay of 110$200 \mathrm{~ms}$ (mean, $131 \pm 46 \mathrm{~ms} ; \mathrm{n}=8$; Figure $3 B$ ), including the application delay of maximally $50 \mathrm{~ms}$. Comparable delays were observed in the receptor-mediated induction of potassium currents and attributed to the initial activation of the $G$ protein-dependent pathway (Inomata et al., 1989; Otis et al., 1993). In 5 out of 8 synapses, the $\mathrm{GABA}_{\mathrm{B}}$-induced inhibition, which varied from $39 \%$ to $85 \%$ (mean, $70 \% \pm 14 \% ; n=10$ ) when measured 1-2 s after application, rose single exponentially with time constants ranging from 110 to $200 \mathrm{~ms}$ with a mean of $173+36$ ms. In 3 out of 8 synapses, inhibition was established with an even faster time course, which could not be resolved owing to the system-limited resolution of $50 \mathrm{~ms}$. To resolve the time course of recovery of EPSCs from steady-state GABA induced inhibition (50 $\mu \mathrm{M}$ baclofen applied for 10-20 $\mathrm{s}$; inhibition by $47 \%-80 \%$; mean, $61 \% \pm 11 \%$; $n=8$ ), steady superfusion of synapses was rapidly terminated by a pulse of negative pressure in the source pipette, and additionally, baclofen was rapidly displaced from synapses by a stream of control solution (Figure 2B). In the 8 synapses analyzed, steady-state block of EPSCs by cadmium was relieved within $0.6 \mathrm{~s}$ (Figure 3C). Figure 3D depicts the decline of the cadmium- and $\mathrm{CABA}_{B}$ receptor-induced presynaptic inhibition after rapid removal of the blockers. The recovery of EPSCs from baclofen-induced inhibition started with a delay of 1.1-2.1 s (mean, $1.7 \pm 0.5 ; n=6$ ), including the time required for solution exchange. In 7 out of 8 synapses, the $\mathrm{GABA}_{B}$ receptor-induced presynaptic inhibition declined with single-exponential time courses and time constants ranging from $\mathbf{1 . 2}$ to $7.2 \mathrm{~s}$ (mean, $3.4 \pm 1.9 \mathrm{~s}$ ), yielding full recovery within several seconds. In summary, fast changes of the baclofen concentration at extracellularly stimulated synapses showed that after maximal activation of GA$\mathrm{BA}_{\mathrm{B}}$ receptors, the inhibition of EPSCs activated with a delay of 50-150 ms and rose exponentially with time constants between 110 and $200 \mathrm{~ms}$. After removal of the agonist, the inhibition declined exponentially with a delay of 0.6-1.5 $\mathrm{s}$ and time constants ranging between 1 and $7 \mathrm{~s}$. This time course of $\mathrm{GABA}_{B}$ receptor-induced presynaptic inhibition is corroborated by the similarly rapid paired-pulse depression of synaptic responses in hippocampal slices, which is also induced by presynaptic GABA $A_{B}$ receptors (Davies et al., 1990; Otis et al., 1993), implying that in hippocampal neurons $\mathrm{GABA}_{B}$ receptors inhibit presynaptic transmitter release through a fast signal-transducing pathway.

\footnotetext{
Voltage-Activated Calcium Currents Evoked by Action Potential-Like Voltage Commands To study $\mathrm{CABA}_{B}$ receptor-mediated modulation of voltage-activated calcium currents under physiologi-
} 
A

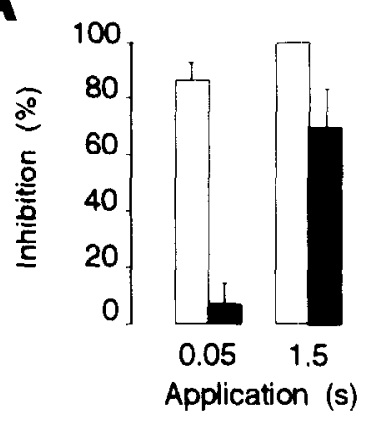

C

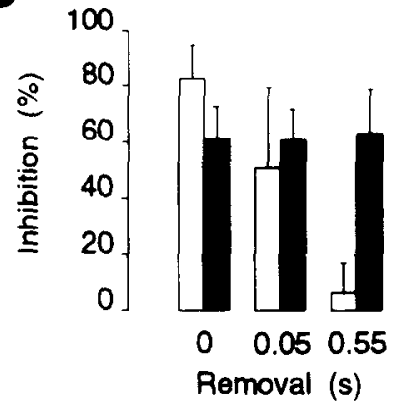

B

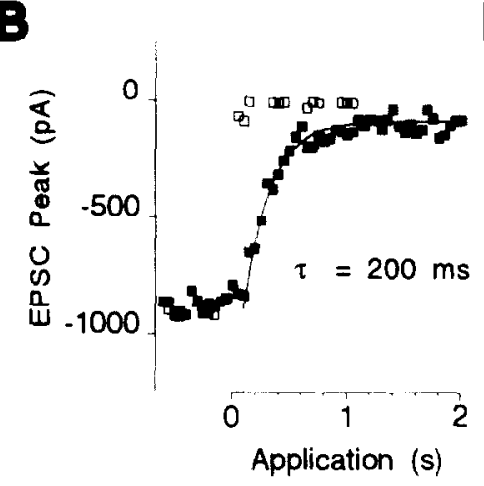

Application (ms)

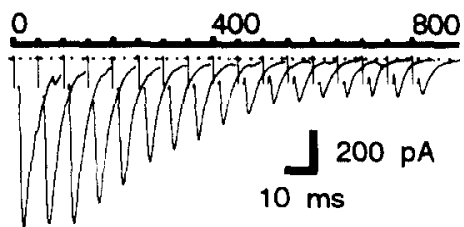

D

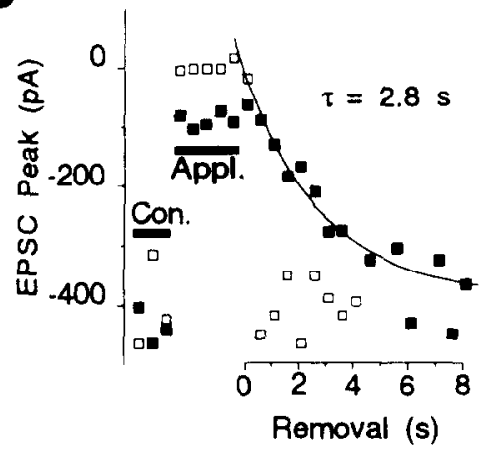

Figure 3. Time Course of the $G A B A_{B}$ Receptor-Mediated Inhibition of Evoked EPSCs after Fast Application and Removal of Baclofen

(A) Inhibition of evoked EPSCs 0.05 and $1.5 \mathrm{~s}$ after fast application of cadmiurn (50 $\mu \mathrm{M}$; open columns) and baclofen (50 $\mu \mathrm{M}$; closed columns); amplitudes were averaged from the 10 synapses analyzed (error bars indicate SD). In all synapses, the agonist was reliably applied within $50 \mathrm{~ms}$, and cadmium did not contaminate the baclofen-induced inhibition as EPSCs were unafferted $50 \mathrm{~ms}$ after application of the agonist.

(B) The onset of the cadmium- (open squares) and the baclofen-(closed squares) induced inhibition of an evoked EPSC was resolved at $50 \mathrm{~ms}$. The rise of the $\mathrm{GABA}_{B}$ receptor-induced inhibition was fitted with a single-exponential function (solid line) with a time constant of $200 \mathrm{~ms}$ (top). After fast application of baclofen, the presynaptic inhibition of the EPSC started with a delay and reached its maximum after $0.5 \mathrm{~s}$ (bottom).

(C) Cadmium- and $\mathrm{GABA}_{\mathrm{B}}$ receptor-induced inhibition of FPSCs during steadystate superfusion and 0.05 and $0.55 \mathrm{~s}$ after fast removal of the blockers; amplitudes were averaged from the 8 synapses analyzed (error bars indicate SD). In all synapses, the agonist was removed within $0.6 \mathrm{~s}$, and the baclofen-induced inhibition was not contaminated by cadmium.

(D) Decline of the inhibition of EPSCs after fast removal of cadmium and baclofen. The decline of the $\mathrm{GABA}_{\mathrm{B}}$ receptor-induced inhibition was slower than the onset, but it could also be fitted with a single-exponential function (solid line) with a time constant of $2.8 \mathrm{~s}$ (top). After fast removal of baclofen, the EPSC recovered from presynaptic inhibition and reached its control amplitude after 4-5 s (bottom).

cal conditions, voltage-gated calcium channels were activated by an action potential-like voltage command (further referred to as spike command) instead of the traditional, rectangular voltage steps. The spike command was derived from action potentials evoked in hippocampal neurons by background synaptic activity (Figure $4 A$, inset). Since voltage steps that are applied with the whole-cell patch clamp are filtered owing to the series resistance and the membrane capacitance (Armstrong and Gilly, 1992; for values see Experimental Procedures), we found it necessary to test how effectively the rapidly rising and decaying spike command could be applied to the somatic membrane and compared the applied spike command with the actual somatic membrane potential by double whole-cell recordings from the same cell. A double whole-cell recording of a spike command applied to a medium-sized neuron $(\phi \approx 30 \mu \mathrm{m})$ with neurites is depicted in the upper panel of Figure 4A. The applied spike command was slowed and diminished. In 7 large neurons $(\phi \approx 50 \mu \mathrm{m})$, comprising at least one neurite, peaks of the actual membrane potential were delayed by $340-600 \mu$ s (mean, $430 \pm 90 \mu \mathrm{s}$ ) and decreased by $16 \%-34 \%$ (mean, $21 \% \pm 6 \%$; or $23 \pm 7 \mathrm{mV}$ ) relative to peaks of the spike command. In 6 small neurons $(\phi \approx 10-20 \mu \mathrm{m})$ without neurites, the delay was $150-$ $250 \mu$ s (mean, $200 \pm 40 \mu \mathrm{s}$ ) with amplitude errors ranging from $3 \%$ to $11 \%$ (mean, $6 \% \pm 3 \%$ or $7 \pm 4 \mathrm{mV}$ ). The double whole-cell recording demonstrated that the action potential-like voltage pulse could be effectively applied to the soma at least in small and medium-sized neurons, in which the slowing and the diminution of the spike potential were tolerable.

Spike-evoked calcium currents through voltagegated channels were isolated by subtracting leak and capacitive currents evoked in the presence of $100 \mu \mathrm{M}$ cadmium (Figure 4A, lower panel). in 5 neurons analyzed with double whole-cell recordings, the delay, between the peaks of the actual membrane potential and the leak-corrected calcium influx, ranged from 


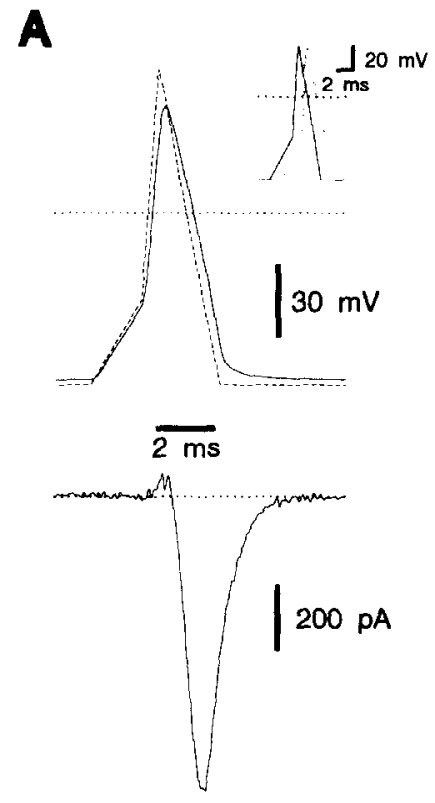

B

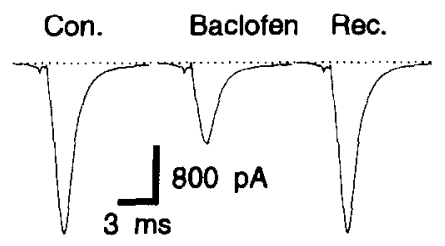

Figure 4. Action Potential-tvoked Calcium Currents

(A) Application of an action potential-like voltage command to a neuron clamped at $-70 \mathrm{mV}$ holding potential. Inset: an action potential recorded from a hippocampal neuron (broken line) and the derived spike command (solid line). Double whole-cell recording (voltage- and current-clamp) from a medium-sized hippocampal neuron (top) to compare the applied spike command (broken line) with the actual membrane potential (solid line). The calcium current evoked by the applied spike command was obtained by subtracting the leak and capacitive current recorded in the presence of $100 \mu \mathrm{M}$ cadmium (bottom).

(B) Spike-evoked calcium currents were reversibly inhibited during superfusion with baclofen $(10 \mu \mathrm{M})$.

0.82 to $1.26 \mathrm{~ms}$ (mean, $0.99 \pm 0.17 \mathrm{~ms} ;$ spike command peak, $+40 \mathrm{mV}$ ). This delay could be attributed to the activation characteristics of voltage-gated calcium channels (Brown et al., 1984). The shape of the spikeevoked calcium influx clearly resembled that reported in previous studies, which also used action potentials to activate calcium currents (Spencer et al., 1989; McCobb and Beam, 1991; Scroggs and Fox, 1992). In 72 neurons, the time-to-peak values $(10 \%-90 \%)$ ranged between 0.46 and $1.23 \mathrm{~ms}$ (mean, $0.83 \pm 0.16 \mathrm{~ms}$ ), and the half amplitude influx lasted from 0.78 to $2.74 \mathrm{~ms}$ (mean, $1.38 \pm 0.30 \mathrm{~ms}$ ). Amplitudes of the calcium influx, measured as time integral over the whole current, ranged from 0.31 to $11.13 \mathrm{nC}$ (mean, $3.0 \pm$ $2.3 \mathrm{nC}$ ).

\section{Baclofen-Induced Inhibition of Spike-Evoked Calcium Currents}

Activation of $\mathrm{CABA}_{\mathrm{B}}$ receptors induces $\mathrm{G}$ proteinmediated inhibition of voltage-activated calcium currents in hippocampal (Scholz and Miller, 1991) and other neurons (Grassi and Lux, 1989; Mintz and Bean, 1993). We confirmed this effect for currents that were evoked with a spike command. As the spike depolarized neurons for about $3 \mathrm{~ms}$, we could study the $\mathrm{GABA}_{B}$ receptor-induced inhibition without voltage-dependent relief, which develops with time constants beyond $4 \mathrm{~ms}$ (Grassi and Lux, 1989; Elmslie et al., 1990; Kasai, 1992). In 20 out of 22 hippocampal neurons, harlofen (10 $\mu \mathrm{M}$ applied for 5-20 s) inhibited spikeevoked calcium influx reversibly by $21 \%-84 \%$ (mean, $47 \% \pm 14 \%$; Figure $4 \mathrm{~B}$ ). Again, as for evoked EPSCs, the amount of inhibition varied, suggesting that individual neurons were differently equipped with the $\mathrm{GABA}_{B}$-induced signaling pathway. The inhibition was mediated by $\mathrm{GABA}_{B}$ receptors, as CGP $35348(500 \mu \mathrm{M})$ significantly reduced the amount of inhibition to $28 \%$ $\pm 15 \% ; n=12 ; p<0.01$ ). PTX-sensitive $G$ proteins mediated the $G A B A_{B}$-induced inhibition of calcium currents, as in PTX-treated cultures $(500 \mathrm{mg} / \mathrm{ml}$; for at least $24 \mathrm{hr}$ ). The baclofen-induced inhibition was completely abolished (mean, $4 \% \pm 5 \% ; n=8$ ) in line with previous studies (Holz et al., 1986; Scholz and Miller, 1991). Thus, $\mathrm{GABA}_{B}$ receptors reduced the spike-evoked calcium influx in cultured hippocampal neurons by activation of PTX-sensitive G proteins.

\section{Kinetics of the $\mathrm{GABA}_{\mathrm{B}}$ Receptor-Mediated Inhibition of Spike-Evoked Calcium Currents}

The $\mathrm{GABA}_{\mathrm{B}}$ receptor-mediated, presynaptic inhibition of EPSCs, which rose and declined exponentially within one and several seconds, respectively, could be caused by the direct depression of presynaptic calcium channels. If this were true, the time courses of the two $\mathrm{GABA}_{\mathrm{B}}$ receptor-induced effects should be similar. Thus, we determined the time course of the inhibition of spike-evoked calcium currents with fast application and removal of baclofen as described above. Calcium influx was evoked with a stimulus interval of $0.2 \mathrm{~s}$, and under control conditions, it decreased by $12.8 \% \pm 5.6 \%(n=8)$ after 30 stimuli. With barium as charge carrier, the decrease was significantly reduced to $4.0 \% \pm 2.3 \%(n=5)$, indicating calcium-dependent inactivation of calcium channels. The small decrease left with barium was probably due to a voltage-dependent component of inactivation, since it was significantly reduced to $1.4 \% \pm 0.6 \%$ ( $n=$ 5 ) with a stimulus interval of $0.6 \mathrm{~s}$. Thus, spike-evoked calcium currents evoked at $5 \mathrm{~Hz}$ decreased owing to voltage- and calcium-dependent inactivation of calcium channels (Morad et al., 1988; Carbone and Swandulla, 1989; Fryer and Zucker, 1993).

The activation kinetics of the $G A B A_{B}$ receptor signaling to voltage-gated calcium channels were investi- 
A

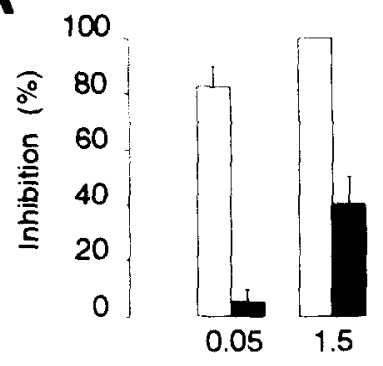

Application (s)

$\mathbf{B}$

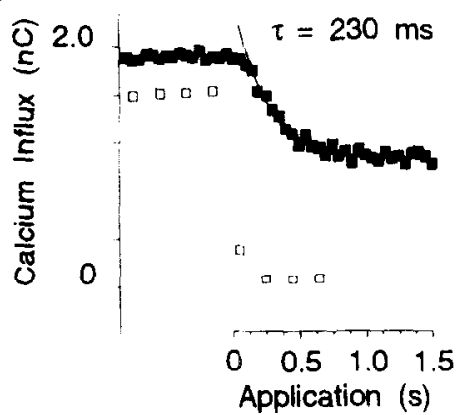

Application (ms)

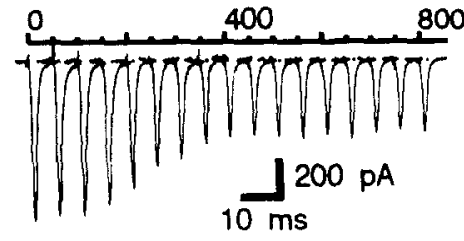

C

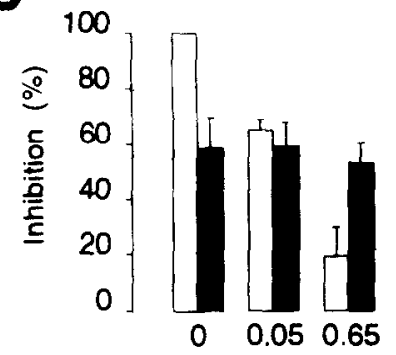

Removal (s)

D
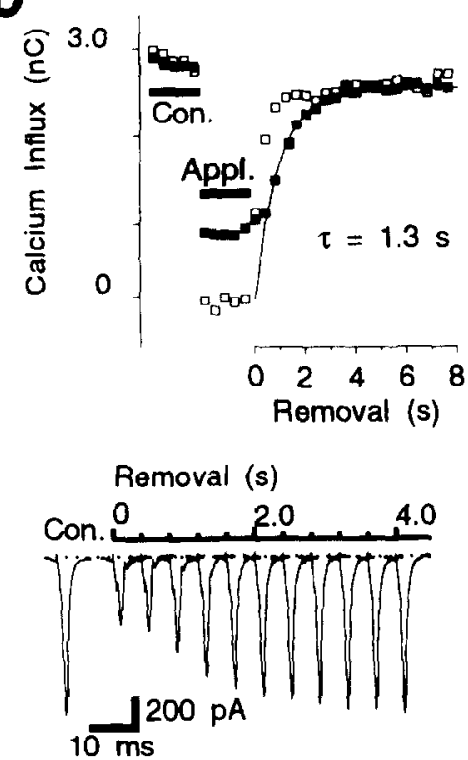

Figure 5. Time Course of the $G A B A_{B}$ Receptor-Mediated Inhibition of SpikeEvoked Calcium Currents after Fast Application and Removal of Baclofen

(A) Inhibition of spike-evoked calcium currents 0.05 and $1.5 \mathrm{~s}$ after fast application of cadmium ( $50 \mu \mathrm{M}$; open columns) and baclofen ( $50 \mu \mathrm{M}$; closed columns); amplitudes were averaged from the 8 neurons analyzed (error bars indicate SD). In all neurons, the agonist was reliably applied within $50 \mathrm{~ms}$, and cadmium did not contaminate the baclofen-induced inhibition. (B) Onset of the cadmium- (open squares) and the $G A B A_{B}$ receptor-induced (closed squares) inhibition of a spike-evoked calcium current resolved at $50 \mathrm{~ms}$. The rise of the baclofen-induced inhibition was fitted with a single-exponential function (solid line) with a time constant of $230 \mathrm{~ms}$ (top). After fast application of baclofen, the inhibition of the spike-evoked calcium current started with a delay and reached its maximum after $0.5 \mathrm{~s}$ (bottom).

(C) Cadmium- and baclofen-induced inhibition during steady-state superfusion and 0.05 and $0.65 \mathrm{~s}$ after fast removal of the blockers; mean of the 9 neurons analyzed (error bars indicate SD). The agonist was removed effectively within $0.7 \mathrm{~s}$, and contamination of the baclofen-induced inhibition by cadmium was excluded.

(D) Decline of the cadmium- and $\mathrm{CABA}_{B}$ receptor-induced inhibition of spikeevoked calcium currents after fast removal of the blockers. The decline of the baclofeninduced inhibition was fitted with a single exponential function (solid line) with a time constant of $1.3 \mathrm{~s}$ (top). After fast removal of baclofen, the calcium current recuvered from inhibition and reached its control amplitude after $4 \mathrm{~s}$ (bottom). gated by fast application of baclofen $(50 \mu \mathrm{M})$ to small and medium-sized neurons. Agonist application within $50 \mathrm{~ms}$ was proved with cadmium in the 12 neurons analyzed (Figure 5A). The distinct time courses of the cadmium- and the baclofen-induced inhibition of spike-evoked calcium currents are depicted in Figure $5 B$. In 8 out of 12 neurons, the $G_{A B A}$ receptor-induced inhibition of the spike-evoked calcium influx started with a delay of 100-200 ms (mean, $131 \pm 46$ $\mathrm{ms} ; \mathrm{n}=8$ ), rose exponentially, and amounted $25 \%$ $56 \%$ (mean, $40 \% \pm 10 \% ; n=12$ ) $1-2$ s after application. The activation time constants ranged from 130 to 290 ms with a mean of $220 \pm 60 \mathrm{~ms}(n=6)$. As for the EPSCs, we observed inhibition of calcium currents with time courses too fast to be resolved quantitatively ( $n=2$ ). Thus, the $\mathrm{GABA}_{B}$ receptor-mediated inhibition of evoked EPSCs and of spike-evoked calcium currents activated with closely matching time courses (Table 1), indicating that the onset of presynaptic inhibition could be determined by the depression of presynaptic calcium channels.

We next studied whether this also held true for the recovery from presynaptic inhibition and analyzed the decline of the $G A B A_{B}$ receptor-mediated inhibition of spike-evoked calcium currents. Figure $5 D$ depicts the different decays of the GABA $A_{B}$ receptor-and the cadmium-induced inhibition of a spike-evoked calcium current. In 9 out of 11 neurons, in which rapid removal was proven (Figure $5 \mathrm{C}$ ), steady-state inhibition $(44 \%-80 \%$; mean, $59 \% \pm 11 \% ; n=11)$ declined exponentially after a delay of 0.5-0.85 s (mean, $0.7 \pm$ $0.1 \mathrm{~s}$ ), with time constants varying from 1.2 to $5.0 \mathrm{~s}$ (mean, $2.2 \pm 1.2 \mathrm{~s}$ ). These values were in a similar range as those we found for the presynaptic inhibition (Table 1), indicating that not only the onset, but also the decline, of the presynaptic inhibition could be determined by the $\mathrm{GABA}_{\mathrm{B}}$ receptor-induced inhibition of spike-evoked calcium currents.

\footnotetext{
Absence of $\mathrm{GABA}_{\mathrm{B}}$ Receptor-Evoked Potassium Currents in Hippocampal Neurons In Vitro In hippocampal slices, $\mathrm{GABA}_{\mathrm{B}}$ receptors also activate potassium currents (Gähwiler and Brown, 1985; Otis et al., 1993), which could mediate presynaptic inhibition of EPSCs. We examined, therefore, whether activation of $\mathrm{GABA}_{\mathrm{B}}$ receptors induced potassium
} 


\begin{tabular}{|c|c|c|c|c|}
\hline \multirow[b]{2}{*}{ Inhibition of } & \multicolumn{2}{|l|}{ Delay $(s)$} & \multicolumn{2}{|l|}{$\tau(\mathrm{s})$} \\
\hline & Min-Max & Mean $\pm S D(n)$ & Min-Max & Mean $\pm S D(n)$ \\
\hline ESSCs & $\begin{array}{l}\text { On } 0.10-0.20 \\
\text { Off } 1.1-2.1\end{array}$ & $\begin{aligned} 0.13 & \pm 0.05(8) \\
1.7 & \pm 0.5(6)\end{aligned}$ & $\begin{array}{c}0.11-0.20 \\
1.2-7.2\end{array}$ & $\begin{aligned} 0.17 & \pm 0.04(5) \\
3.4 & \pm 1.9(7)\end{aligned}$ \\
\hline Calcium currents & $\begin{array}{l}\text { On } 0.10-0.20 \\
\text { Off } 0.5-0.9\end{array}$ & $\begin{aligned} 0.13 & \pm 0.05(8) \\
0.7 & \pm 0.1(9)\end{aligned}$ & $\begin{array}{c}0.13-0.28 \\
t .2-5.0\end{array}$ & $\begin{aligned} 0.22 & \pm 0.06(6) \\
2.2 & \pm 1.2(9)\end{aligned}$ \\
\hline
\end{tabular}

currents in cultured hippocampal neurons. Baclofen (10 or $50 \mu \mathrm{M}$ ) was applied to neurons, clamped at $-30 \mathrm{mV}$ holding potential with GTP $(2 \mathrm{mM})$ and ATP $(1 \mathrm{mM})$ added intracellularly to optimize conditions for $G$ protein activation. In only 7 out of 42 cells, superfusion with baclofen induced small outward currents (mean amplitude, $13 \pm 7 \mathrm{pA}$ ). Thus, we found that in the majority of hippocampal neurons in vitro, $G_{A B A_{B}}$ receptors did not couple to potassium channels. A similar lack of $G A B A_{B}$ receptor-induced potassium currents has been reported previously in embryonic neurons (Harrison, 1990). It may be due to absent expression of necessary signal-transducing proteins in immature neurons (Janigro and Schwartzkroin, 1988) or due to a culture-conditioned defect in the signaling pathway.

\section{Discussion}

This study revealed that in hippocampal neurons in vitro, the $\mathrm{GABA}_{B}$ receptor-induced inhibition of evoked EPSCs and of spike-evoked calcium currents rose and declined with very similar kinetics, indicating that presynaptic $\mathrm{CABA}_{B}$ receptors may inhibit excitatory synaptic transmission by depressing voltagegated calcium channels and thus decreasing the calcium influx that triggers transmitter release. The fast kinetics of the $\mathrm{GABA}_{B}$ receptor-induced inhibition of spike-evoked calcium currents indicated that the signal transduction involves a tight, membranedelimited coupling of $G A B A_{B}$ receptor-activated $G$ proteins to voltage-gated calcium channels.

\section{Presynaptic Inhibition Due to Depression of Voltage-Gated Calcium Channels}

Presynaptic $G_{A B A} A_{B}$ receptors inhibit excitatory synaptic transmission between hippocampal (Dutar and Nicoll, 1988; Forsythe and Clements, 1990; Thompson and Gähwiler, 1992) as well as other neurons of the CNS (Howe et al., 1987; Seabrook et al., 1990; Alford and Grillner, 1991). This inhibition could be effectively brought about by the $\mathrm{G}$ protein-mediated depression of voltage-gated calcium channels, which has been demonstrated in neurons from different regions of the nervous system (Grassi and Lux, 1989; Mintz and Bean, 1993). In hippocampal neurons, however, the coupling of $G A B A_{B}$ receptors to calcium channels has been questioned owing to an early study (Gähwiler and Brown, 1985), and consequently, presynaptic inhibition in the hippocampus has been attributed to other $\mathrm{GABA}_{B}$ receptor-induced effects (Thompson et al., 1993). In line with Scholz and Miller (1991), we show that in cultured hippocampal neurons, $G A B A_{B}$ receptors markedly reduced voltage-activated calcium currents and that the inhibition was mediated by PTX-sensitive $G$ proteins. The expression of this $\mathrm{CABA}_{\mathrm{B}}$ receptor-induced effect in cultured hippocampal neurons suggested that depression of voltagegated calcium channels could have caused the presynaptic inhibition of evoked EPSCs. We thus examined the time courses of the baclofen-induced presynaptic inhibition and the reduction of spike-activated calcium currents after step-like changes of the agonist concentration and found a good agreement of the kinetic properties of both effects, as these developed and declined with exponential kinetics and similar time constants (Table 1). Thus, the kinetic data support the hypothesis that in hippocampal neurons in vitro, the depression of presynaptic, voltage-gated calcium channels may be one mechanism of the $G A B A_{B}$ receptor-induced inhibition of synaptic transmission.

Clearly, our data do not rule out that other $\mathrm{GABA}_{B}$ receptor-induced effects contribute to presynaptic inhibition of synaptic transmission. $G A B A_{B}$ receptorinduced potassium currents (Gähwiler and Brown, 1985; Nicoll et al., 1990; Sivilotti and Nistri, 1991; Gage, 1992; Bowery, 1993) could inhibit evoked EPSCs by hyperpolarizing presynaptic terminals and thus reducing the action potential, since these currents activate similarly fast (Otis et al., 1993) as the presynaptic inhibition reported here and are similarly sensitive to PTX (Andrade et al., 1986) and CGP 35348 (Solis and Nicoll, 1992). The absence of whole-cell somatic potassium currents which we observed does not rule out that, in presynaptic terminals, $\mathrm{GABA}_{B}$ receptors couple to potassium channels. However, compared with the $G A B A_{B}$ receptor-induced inhibition of evoked EPSCs, potassium currents activated by postsynaptic $\mathrm{GABA}_{B}$ receptors decrease 10 -fold more rapidly (Otis et al., 1993). Similarly, Otis et al. (1993) reported that paired-pulse inhibition of synaplic transmission also decreases more slowly than the $\mathrm{GABA}_{B}$ receptor-induced potassium current. Assuming that presynaptically and postsynaptically induced potassium currents have similar kinetics, this indicates that presynaptic inhibition is mediated by additional mechanisms with relatively slow decrease. In comparing pharmacological sensitivities, previous authors concluded that $\mathrm{GABA}_{B}$ receptor-induced potassium currents do not cause presynaptic inhibition of excitatory synaptic 
transmission (Thompson and Gähwiler, 1992; Lambert and Wilson, 1993), but rather inhibitory synaptic transmission (Thompson and Gähwiler, 1992). The baclofen-induced increase of a voltage-dependent potassium current (Saint et al., 1990) does not appear to contribute to presynaptic inhibition, since, in contrast with inhibition of evoked EPSCs, this effect is insensitive to PTX (see Gage, 1992). In addition to their effects on ionic currents, $\mathrm{GABA}_{B}$ receptors could cause presynaptic inhibition by inhibition of the adenylate cyclase (Jenks et al., 1991; Travagli et al., 1991). Furthermore, there is increasing evidence that $\mathrm{G}$ proteincoupled receptors (Man-Son-Hing et al., 1989; Scholz and Miller, 1992; Rekling, 1993), including the $G_{A B A_{R}}$ type (Scanziani et al., 1992), may cause presynaptic inhibition by interfering directly with the release apparatus. If the latter signal transduction pathways contribute to presynaptic inhibition, their time courses should meet those we described here.

\section{$\mathrm{CABA}_{\mathrm{B}}$ Receptors Inhibit Voltage-Gated Calcium Channels through a Fast Pathway}

The molecular components involved in the $\mathrm{GABA}_{B}$ receptor-induced depression of voltage-gated calcium channels have been studied previously. There is a considerable amount of evidence that beneath $G$ proteins, neither cytoplasmic second messengers nor protein kinases mediate the signaling (Green and Cottrell, 1988; Diversé-Pierlussi and Dunlap, 1993; for reviews see also Dolphin, 1990; Schultz et al., 1990; Anwyl, 1991) and indication (Bean, 1989; Grassi and Lux, 1989; Kasai 1992) that $G$ proteins mediate calcium channel inhibition by a membrane-delimited pathway (Brown, 1993). The fast onset of the $G A B A_{B}$ receptorinduced inhibition of spike-evoked calcium currents we describe supports this conclusion. The $G A B A_{B}$ receptor-mediated inhibition developed similarly fast as noradrenergic and the fast component of muscarinic inhibition (Bernheim et al., 1991) and even faster than glutamatergic inhibition (Swartz and Bean, 1992) of voltage-activated calcium currents. The fast actions of these neurotransmitters on calcium channels appear not to involve readily diffusible second messengers. Furthermore, signal transduction between $\mathrm{GABA}_{B}$ receptors and voltage-gated calcium channels activates similarly fast as the membrane-delimited signaling between muscarinic receptors and potassium channels (Yatani et al., 1987; Inomata et al., 1989). In several but not all neurons, calcium currents and EPSCs were found maximally depressed within 150 ms. Similarly rapid inhibition of calcium currents by other neurotransmitters has been previously reported (Bean, 1989; Jones, 1991; Pollo et al., 1992), hut these very fast effects were inconsistently observed. Other studies on time courses of receptor-induced calcium current inhibition, however, reported slower onset rates even though solution exchanges $(\leqslant 100 \mathrm{~ms})$ were similarly fast (Boland and Bean, 1993; Sahara and Westbrook, 1993). This may indicate different signaling mechanisms.
After removal of baclofen, the $G A B A_{B}$ receptor-induced inhibition of spike-evoked calcium currents decayed with time constants of several seconds. Decreases with similar time courses have been reported for inhibition of voltage-activated calcium currents by different $G$ protein-coupled receptors (Bernheim et al., 1991; Jones, 1991; Swartz and Bean, 1992; Pollo et al., 1992). The muscarinic potassium current decays with a faster time course (Nargeot et al., 1982; Breitwieser and Szabo, 1988), and the decay of the GABA receptor-induced potassium current has a clearly faster component (Otis et al., 1993). However, in the case of $\mathrm{G}$ protein-mediated current induction, the deactivation might be caused by a fast, channelintrinsic process. Since the coupling between $G A B A_{B}$ receptors and voltage-gated calcium channels probably does not involve soluble second messengers, the signal transduction could be rate limited by the $G$ protein activation and deactivation cycle (Birnbaumer et al., 1990), as previously suggested for the muscarinic activation of potassium channels (Breitwieser and Szabo, 1988).

\section{Experimental Procedures}

\section{Cell Culture and Drugs}

Hippocampi from embryonic rats (embryonic day 19) were triturated with fire-polished pasteur pipettes without prior enzymatic treatment in chilled Earl's buffered salt solution, supplemented with penicillin, streptomycin, and fungizone, but with no calcium added (GIBCO, Life Technologies, Eggenstein, Germany). Dissociated cells were plated on polyornithine-/laminin-coated culture dishes (density $=4 \cdot 10^{4}$ to $6 \cdot 10^{4}$ cells per $\mathrm{cm}^{2}$ ) and cultured with $5 \% \mathrm{CO}_{2}$ in Eagle's basal medium, which was supplemented with horse serum (10\%), l-glutamine, glucose, insulin, penicillin, and streptomycin (GIBCO). After 3 days in vitro, proliferation of glial cells was minimized by adding cytosine- $\beta$-D. arabinofuranoside hydrochloride $(10 \mu M)$ (Sigma Chemie, Deisenhofen, Germany) for $24 \mathrm{hr}$ to the culture medium. Cultures were viable up to 14 days and used after at least 6 days. Baclofen was purchased from Research Biochemicals Inc. (Köln, Germany). The selective $G A B A_{B}$ receptor antagonist CGP 35348 was a kind gift of CIBA-GEIGY (Basel, Switzerland). For treatment with PTX (RBI), the toxin was added to the culture medium for at least $24 \mathrm{hr}$ at a concentration of $500 \mathrm{ng} / \mathrm{ml}$.

\section{Electrophysiological Recording}

Currents were recorded using the whole-cell configuration of the patch-clamp technique (Hamill et al., 1981) with an EPC 7 amplifier (List-Medical, Darmstadt, Germany) and the pCLAMP hard- and software (Axon Instruments, Inc., Foster City, CA). Patch pipettes of borosilicate glass had resistances between 3 and $10 \mathrm{M} \Omega$. Experiments were carried out at $18^{\circ} \mathrm{C}-22^{\circ} \mathrm{C}$. EPSCs were evoked by extracellular stimulation of presynaptic axons (Figure 2A). Short $(200 \mu s)$ current pulses from an isolated stimulator (Hi-Med) were delivered through a patch pipette, which was filled with a mixture (1:1) of extracellular solution and $1 \mathrm{M} \mathrm{NaCl}$ and grounded through the bath reference. EPSCs were recorded at a holding potential of $-70 \mathrm{mV}$ in $125 \mathrm{mM} \mathrm{NaCl}, 5 \mathrm{mM} \mathrm{KCl}$, $3 \mathrm{mM} \mathrm{CaCl}_{2}, 2 \mathrm{mM} \mathrm{MgCl}, 10 \mathrm{mM}$ HEPES $(\mathrm{pH} 7.4$ with $50 \mu \mathrm{M}$ bicuculline methchloride or -iodide [Sigma] added). The intracellular recording solution contained $110 \mathrm{mM} \mathrm{KCl}, 0.25 \mathrm{mM} \mathrm{CaCl}_{2}$, $10 \mathrm{mM}$ EGTA, and $10 \mathrm{mM}$ HEPES (pH 7.4). Voltage-activated sodium currents, elicited in postsynaptic neurons by the extracellular stimulation, disturbed evoked EPSCs and were blocked with the quarternary lidocaine derivative QX-314 (20 mM; RBI) added to the intracellular recording solution. Whole-cell current-clamp recordings from hipporampal pyramidal neurons confirmed 
that QX-314 (20 mM) suppressed sodium-dependent action potentials within 2 min after breaking the patch $(n=5$; data not shown) as previously reported (Connors and Prince. 1982; Isaac and Wheal, 1993). For the kinetic analysis, EPSCs were evoked with a stimulus interval of $0.3 \mathrm{~s}$, which decreased peak amplitudes by $51 \% \pm 18 \%(n-10)$ after 10 stimuli, with a stable amplitude thereafter.

Voltage-activated calcium currents were recorded in a sodium-free extracellular solution $(130 \mathrm{mM}$ tetraethylammonium chloride, $5 \mathrm{mM} \mathrm{CaCl}_{2}, 10 \mathrm{mM} \mathrm{HEPES}$ [pH 7.4]), with the intracellular solution containing $100 \mathrm{mM} \mathrm{CsCl}, 0.25 \mathrm{mM} \mathrm{CaCl}, 10 \mathrm{mM}$ EGTA, $20 \mathrm{mM}$ tetraethylammonium chloride, and $10 \mathrm{mM}$ HEPES (pH 7.4 with $1 \mathrm{mM} \mathrm{Mg}-A T P$ and $2 \mathrm{mM} \mathrm{Na}$-CTP added). Estimates of series resistances were gained according to Armstrong and Gilly (1992) by analyzing currents that were evoked by depolarizing voltage steps $(-70$ to $-60 \mathrm{mV} ; 50 \mathrm{~ms})$. As the measurements were done in the solutions used for calcium current recording, membrane resistances were high (1-7 G $\Omega$; mean, $4 \pm 2 \mathrm{G} \Omega$; $n$ $=7$. Series resistances were calculated from the fastest time constant of the decay of the capacitive current component (Jackson, 1992) divided by the membrane capacitance (6.1-26.2 pF; mean, $16.2 \pm 5.9 \mathrm{pF} ; \mathrm{n}=18$ ). Values ranged from 6 to $20 \mathrm{M} \Omega$ (mean, $11.4+4.2 \mathrm{M} \Omega ; \mathrm{n}=18$ ). The membrane capacitance and the series resistance (for maximally $50 \%$ ) were compensated with the analog circuits of the patch-clamp amplifier. The spike command used to activate voltage-gated calcium channels was derived from action potentials evoked by spontaneous synaptic activity in high density cultures. In the inset in Figure $4 \mathrm{~A}$, a recorded action potential (broken line) and the derived spike command are depicted. From the holding potential $(-70 \mathrm{mV})$, the command potential rose within $1.75 \mathrm{~ms}$ to a threshold of -35 $\mathrm{mV}$, reached the peak value $(+40 \mathrm{mV})$ within $450 \mu \mathrm{s}$, and repolarized to $-70 \mathrm{mV}$ within $1.8 \mathrm{~ms}$.

\section{Superfusion Techniques for Fast Application and Removal of Receptor Agonists}

The superfusion technique, originally introduced by Streit and Lux (1989), was modified to allow fast application (Leßmann et al., 1992) and removal of receptor agonists. For fast application, a laminar stream of agonist-containing solution, which formed between two oppositely placed glass pipettes $(\phi \approx 20$ and $50 \mu \mathrm{m})$ under positive (source pipette) and negative (suction pipette) hydrostatic pressure, was positioned close to the region to be superfused (Figure 2A). A valve-controlled pressure increase in the source pipette rapidly expanded the stream, thus superfus ing the nearby cell or synapse. For fast removal of the agonist, a pulse of negative pressure in the source pipette terminated steady superfusion. Additionally, the agonist was rapidly displaced by simultaneously extending a nearby stream of agonistfree control solution, delivered from a second source pipette (Figure 2B). The performance of the superfusion system was tested by blocking high voltage-activated calcium currents by cadmium in neurons with few and short neurites (Figures $2 \mathrm{~A}$ bottom, and $2 \mathrm{~B}$, bottom). The kinetics of the cadmium-induced block should reliably measure the efficiency of application and removal. After fast application of cadmium, the delay of block onset, the system dead time, ranged from 8 to $14 \mathrm{~ms}$ with a mean value of $10 \pm 2 \mathrm{~ms}(n=14)$. High voltage-activated (HVA) calcium currents were blocked by more than $85 \%, 50 \mathrm{~ms}$ after cadmium application (mean, $94 \% \pm 7 \% ; n=9$; Figure $2 \mathrm{~A}$, bottom). The efficiency of removal was tested by removing steady-state cadmium block from HVA calcium currents. Current amplitudes recovered to at least $80 \%$ of control (mean, $89 \%+7 \% ; n=15$ ) $50 \mathrm{~ms}$ after removal of cadmium (Figure 2B, bottom). Before the kinetics of the $G A B A_{B}$-induced inhibition were analyzed, fast solution changes at individual synapses and neurons were tested with cadmium. The positions of the superfusion pipettes were adjusted until inhibition of EPSCs and calcium currents was fully established or removed by application of cadmium or control solution. Thereafter, the baclofen-containing delivery barrel of the multibarreled system was switched on. Prior to baclofen application to cells, washout for several seconds ascertained complete removal of cadmium.
To analyze the onset of the baclofen-induced inhibition at the maximally possible resolution $(50 \mathrm{~ms})$, we used the following application and stimulation paradigm: After control EPSCs or calcium currents were evoked with stimulus intervals of 0.3 and $0.2 \mathrm{~s}$, respectively, baclofen was applied $50 \mathrm{~ms}$ before the first test stimulus with the application pulse lasting for $1 \mathrm{~s}$. In each subsequent trial, the interval between the baclofen application and the first test stimulus was prolonged by $50 \mathrm{~ms}$. The time course of inhibition was obtained by combining these trials.

\section{Acknowledgments}

This work was supported in part by the Deutsche Forschungsgemeinschaft SFB 220 (A1).

The costs of publication of this article were defrayed in part by the payment of page charges. This article must therefore be hereby marked "advertisement" in accordance with 18 USC Section 1734 solely to indicate this fact.

Received August 9, 1993; revised Ortoher 26, 1993.

\section{References}

Alford, S., and Grillner, S. (1991). The involvement of GABA receptors and coupled G-proteins in spinal GABAergic presynaptic inhibition. J. Neurosci. 11, 3718-3726.

Andrade, R. (1991). Blockade of neurotransmitter-activated K+ conductance by QX-314 in the rat hippocampus. Eur. J. Pharma col. 199, 259-262.

Andrade, R., Malenka, R. C., and Nicoll, R. A. (1986). A G protein couples serotonin and $\mathrm{CABA}_{B}$ receptors to the same channels in hippocampus. Science 234, 1261-1265.

Anwyl, R. (1991). Modulation of vertebrate neuronal calcium channels by transmitters. Brain Res. Rev. 16, 265-281.

Armstrong, C. M., and Gilly, W. F. (1992). Access resistance and space clamp problems associated with whole-cell patch clamping. In Methods in Enzymology, Volume 207: Ion Channels, B. Rudy and L. E. Iverson, eds. (New York: Academic Press, Inc.), pp. 100-122.

Bean, B. P. (1989). Neurotransmitter inhibition of neuronal calcium currents by changes in channel voltage dependence. $\mathrm{Na}$ ture $340,153-156$.

Bernheim, L., Beech, D. J., and Hille, B. (1991). A diffusible second messenger mediates one of the pathways coupling receptors to calcium channels in rat sympathetic neurons. Neuron 6,859 867.

Birnbaumer, L., Abramowitz, J., and Brown, A. M. (1990). Receptor-effector coupling by $\mathrm{G}$ proteins. Biochim. Biophys. Acta 1031, 163-224.

Boland, L. M., and Bean, B. P. (1993). Modulation of N-type calcium channels in bullfrog sympathetic neurons by luteinizing hormone-releasing hormone: kinetirs and voltage dependence. J. Neurosci. 13, 516-533.

Bowery, N. G. (1989). GABA $A_{B}$ receptors and their significance in mammalian pharmacology. Trends Pharmacol. Sci. 10, 401-407. Bowery, N. G. (1993). GABA ${ }_{B}$ receptor pharmacology. Annu. Rev. Pharmacol. Toxicol. 33, 109-147.

Breitwieser, G. E., and Szabo, G. (1988). Mechanism of muscarinic receptor-induced $\mathrm{K}+$ channel activation as revealed by hydrolysis-resistant GTP analogues. J. Gen. Physiol. 91, 469-493.

Brown, A. M. (1993). Membrane-delimited cell signaling complexes: direct ion channel regulation by G-proteins. J. Membr. Biol. 131, 93-104.

Brown, A. M., Lux, H. D., and Wilson, D. L. (1984). Activation and inactivation of single calcium channels in snail neurons. J. Gen. Physiol. 83, 751-769.

Carbone, E., and Swandulla, D. (1989). Neuronal calcium channels: kinetics, blockade and modulation. Prog. Biophys. Mol Biol. 54, 31-58.

Colmers, W. F., and Pittman, Q. J. (1989). Presynaptic inhibition 
by neuropeptide $Y$ and baclofen in hippocampus: insensitivity to pertussis toxin treatment. Brain Res. 498, 99-104.

Connors, B. W., and Prince, D. A. (1982). Effects of local anesthetic QX-314 on the membrane properties of hippocampal pyramidal neurons. J. Pharmacol. Exp. Ther. 220, 476-481.

Crunelli, $V_{.}$, and Leresche, N. (1991). A role for $\mathrm{GABA}_{\mathrm{B}}$ receptors in excitation and inhibition of thalamocortical cells. Trends Neurosci. 14, 16-21.

Davies, C. H., Davies, S. N., and Collingridge, G. L. (1990). Pairedpulse depression of monosynaptic GABA-mediated inhibitory postsynaptic responses in rat hippocampus. J. Physiol. 424, 513531.

Diversé-Pierluissi, M., and Dunlap, K. (1993). Distinct, convergent second messenger pathways modulate neuronal calcium currents. Neuron 10, 753-760.

Dolphin, A. C. (1990). G protein modulation of calcium currents in neurons. Annu. Rev. Physiol. 52, 243-255.

Dutar, P., and Nicoll, R. A. (1988). Pre- and postsynaptic GABA $A_{B}$ receptors in the hippocampus have different pharmacological properties. Neuron 1, 585-591.

Eimslie, K. S., Zhou, W., and Jones, S. W. (1990). LHRH and GTP- $\gamma$-S modify calcium current activation in bullfrog sympathetic neurons. Neuron 5, 75-80.

Forsythe, I. D., and Clements, J. D. (1990). Presynaptic glutamate receptors depress excitatory monosynaptic transmission between mouse hippocampal neurones. J. Physiol. 429, 1-16.

Fryer, M. W., and Zucker, R. S. (1993). $\mathrm{Ca}^{2^{+}}$-dependent inactivation of $\mathrm{Ca}^{2+}$ current in Aplysia neurons: kinetic-studies using photolabile $\mathrm{Ca}^{2+}$ chelators. J. Physiol. 464, 501-528.

Gage, P. W. (1992). Activation and modulation of neuronal $\mathrm{K}^{+}$ channels by GABA. Trends Neurosci. 15, 46-51.

Gähwiler, B. H., and Brown, D. A. (1985). GABA Breceptor- $^{-}$ activated $\mathrm{K}+$ current in voltage-clamped $\mathrm{CA} 3$ pyramidal cells in hippocampal cultures. Proc. Natl. Acad. Sci. USA 82, 1558-1562. Grassi, F., and Lux, H. D. (1989). Voltage-dependent GABAinduced modulation of calcium currents in chick sensory neurons. Neurosci. Lett. 105, 113-119.

Green, K. A., and Cottrell, G. A. (1988). Actions of baclofen on components of the Ca-current in rat and mouse DRG neurones in culture. Br. J. Pharmacol. 94, 235-245.

Hamill, O. P., Marty, A., Neher, E., Sakmann, B., and Sigworth, F. J. (1981). Improved patch-clamp techniques for high-resolution current recording from cells and cell-free patches. Pflügers Arch. 397, 85-100.

Harrison, N. L. (1990). On the presynaptic action of baclofen at inhibitory synapses between cultured rat hippocampal neurones. J. Physiol. 422, 433-446.

Holz, G. G., IV, Rane, S. G., and Dunlap, K. (1986). GTP-binding proteins mediate transmitter inhibition of voltage-dependent calcium channels. Nature 319, 670-672.

Holz, G. G., IV, Kream, R. M., Spiegel, A., and Dunlap, K. (1989). $G$ proteins couple $\alpha$-adrenergic and $G A B A_{B}$ receptors to inhibition of peptide secretion from peripheral sensory neurons. J. Neurosci. 9, 657-666.

Howe, J. R., Sutor, B., and Zieglgänsberger, W. (1987). Baclofen reduces post-synaptic potentials of rat cortical neurones by an action other than its hyperpolarizing action. J. Physiol. 384, 539569.

Huston, E., Scott, R. H., and Dolphin, A. C. (1990). A comparison of the effect of calcium channel ligands and $\mathrm{GABA}_{B}$ agonists and antagonists on transmitter release and somatic calcium channel currents in cultured neurons. Neuroscience 38, 721-729.

Inomata, N., Ishihara, T., and Akaike, N. (1989). Activation kinetics of the acetylcholine-gated potassium current in isolated atrial cells. Am. J. Physiol. 257, C646-C650.

Isaac, J. T., and Wheal, H. V. (1993). The local-anesthetic QX-314 enables enhanced whole-cell recordings of excitatory synaptic currents in rat hippocampal slices in vitro. Neurosci. Lett. 150, 227-230.
Jackson, M. B. (1992). Cable analysis with whole-cell patch clamp. Theory and experiment. Biophys. J. 61, 756-766.

Janigro, D., and Schwartzkroin, P. A. (1988). Effects of CABA and baclofen on pyramidal cells in the developing rabbit hippocampus: an 'in vitro' study. Dev. Brain Res. 41, 171-184.

Jenks, B. G., Van Zoest, I. D., De Koning, H. P., Leenders, H. J., and Roubos, E. W. (1991). The CRF-related peptide sauvagine stimulates and the $\mathrm{GABA}_{B}$ receptor agonist baclofen inhibits $c y$ clic-AMP production in melanotrope cells of Xenopus laevis. Life Sci. 48, 1633-1637.

Jones, S. W. (1991). Time course of receptor-channel coupling in frog sympathetic neurons. Biophys. J. 60, 502-507.

Kasai, H. (1992). Voltage- and time-dependent inhibition of neuronal calcium channels by a GTP-binding protein in a mammalian cell line. J. Physiol. 448, 189-209.

Lambert, N. A., and Wilson, W. A. (1993). Discrimination of postsynaptic and presynaptic $G A B A_{B}$ receptor-mediated responses by tetrahydroaminoacridine in area $\mathrm{CA} 3$ of the rat hippocampus. J. Neurophysiol. 69, 630-635.

Leßmann, V., Gottmann, K., and Lux, H. D. (1992). Evans blue reduces macroscopic desensitization of non-NMDA receptor mediated currents and prolongs excitatory postsynaptic currents in cultured rat thalamic neurons. Neurosci. Lett. 146, 13-16.

Man-Son-Hing, H., Zoran, M. J., Lukowiak, K., and Haydon, P. G. (1989). A neuromodulator of synaptic transmission acts on the secretory apparatus as well as ion channels. Nature 341,237 239.

McCobb, D. P., and Beam, K. G. (1991). Action potential waveform voltage-clamp commands reveal striking differences in calcium entry via low and high voltage-activated calcium channels. Neuron 7, 119-127.

Miller, R. J. (1990). Receptor-mediated regulation of calcium channels and neurotransmitter release. FASEB J. 4, 3291-3299.

Milligan, G. (1988). Techniques used in the identification and analysis of function of pertussis toxin-sensitive guanine nucleotide binding proteins. Biochem. J. 255, 1-13.

Mintz, I. M., and Bean, B. P. (1993). GABA ${ }_{B}$ receptor inhibition of P-type $\mathrm{Ca}^{2+}$ channels in central neurons. Neuron 10, 889-898. Morad, M., Davies, N. W., Kaplan, J. H., and Lux, H. D. (1988). Inactivation and block of calcium channels by photo-released $\mathrm{Ca}^{2+}$ in dorsal root ganglion neurons. Science 241, 842-844.

Morishita, R., Kato, K., and Asano, T. (1990). GABA ${ }_{B}$ receptors couple to $G$ proteins $G_{0}, G_{0}{ }^{*}$ and $G_{i 1}$ but not to $G_{i 2}$. FEBS Lett. 271, 231-235.

Nargeot, J., Lester, H. A., Birdsall, N. J. M., Stockton, J., Wassermann, N. H., and Erlanger, B. F. (1982). A photoisomerizable muscarinic antagonist: studies of binding and of conductance relaxations in frog heart. J. Gen. Physiol. 79, 657-678.

Nathan, T., Jensen, M. S., and Lambert, J. D. (1990) The slow inhibitory postsynaptic potential in rat hippocampal CA1 neurones is blocked by intracellular injection of QX-314. Neurosci. Lett. 110, 309-313.

Nicoll, R. A., Malenka, R. C., and Kauer, J. A. (1990). Functional comparison of neurotransmitter receptor subtypes in mammalian central nervous system. Physiol. Rev. 70, 513-565.

Olpe, H. R., Karlsson, G., Pozza, M. F., Brugger, F., Steinmann, M., Van-Riezen, H., Fagg, G., Hall, R. G., Froestl, W., and Bittiger, H. (1990). CGP 35348: a centrally active blocker of $G A B A_{B}$ receptors. Eur. J. Pharmacol. 187, 27-38.

Otis, T. S., De Koninck, Y., and Mody, I. (1993). Characterization of synaptically elicited $C A B A_{B}$ responses using patch-clamp recordings in rat hippocampal slices. J. Physiol. 463, 391-407.

Pfrieger, F. W., Veselovsky, N. S., Gottmann, K., and Lux, H. D. (1992). Pharmacological characterization of calcium currents and synaptic trans mission between thalamic neurons in vitro. I. Neurosci. 12, 4347-4357.

Pollo, A., Lovallo, M., Sher, E., and Carbone, E. (1992). Voltagedependent noradrenergic modulation of $\omega$-conotoxin-sensitive 
$\mathrm{Ca}^{2+}$ channels in human neuroblastoma IMR32 cells. Pflügers Arch. 422, 75-83.

Rekling, J. C. (1993). Effects of met-enkephalin on GABAergic spontaneous miniature IPSPs in organotypic slice cultures of the rat hippocampus. ). Neurosci. 13, 1954-1964.

Sahara, Y., and Westbrook, G. L. (1993). Modulation of calcium currents by a metabotropic glutamate receptor involves fast and slow kinetic components in cultured hippocampal neurons. J. Neurosci. 13, 3041-3050.

Saint, D. A., Thomas, T., and Gage, P. W. (1990). GABA $A_{B}$ agonists modulate a transient potassium current in cultured mammalian hippocampal neurons. Neurosci. Lett. 118, 9-13.

Scanziani, M., Capogna, M., Gähwiler, B. H., and Thompson, S. M. (1992). Presynaptic inhibition of miniature excitatory synaptic currents by baclofen and adenosine in the hippocampus. Neuron 9, 919-927.

Scholz, K. P., and Miller, R. J. (1991). GABA $A_{B}$ receptor-mediated inhibition of $\mathrm{Ca}^{2+}$ currents and synaptic transmission in cultured rat hippocampal neurones. J. Physiol. 444, 669-686.

Scholz, K. P., and Miller, R. J. (1992). Inhibition of quantal transmitter release in the absence of calcium influx by a $G$ proteinlinked adenosine receptor at hippocampal synapses. Neuron 8 , 1139-1150.

Schultz, G., Rosenthal, W., Hescheler, J., and Trautwein, W. (1990). Role of $G$ proteins in calcium channel modulation. Annu. Rev. Physiol. 52, 275-292.

Scott, R. H., Pearson, H. A., and Dolphin, A. C. (1991). Aspects of vertebrate neuronal voltage-activated calcium currents and their regulation. Prog. Neurobiol. 36, 485-520.

Scroggs, R. S., and Fox, A. P. (1992). Multiple $\mathrm{Ca}^{2+}$ currents elicited by action-potential waveforms in acutely isolated adult rat dorsal root ganglion neurons. J. Neurosci. 12, 1789-1801.

Seabrook, G. R., Howson, W., and Lacey, M. G. (1990). Electrophysiological characterization of potent agonists and antagonists at pre- and postsynaptic $\mathrm{GABA}_{\mathrm{B}}$ receptors on neurones in rat brain slices. Br. J. Pharmacol. 101, 949-957.

Sivilotti, L., and Nistri, A. (1991). GABA receptor mechanisms in the central nervous system. Prog. Neurobiol. 36, 35-92.

Solis, J. M., and Nicoll, R. A. (1992). Pharmacological characterization of $\mathrm{GABA}_{\mathrm{B}}$-mediated responses in the $\mathrm{CA1}$ region of the rat hippocampal slice. J. Neurosci. 12, 3466-3472.

Spencer, A. N., Przysiezniak, J., Acosta-Urquidi, J., and Basarsky, T. A. (1989). Presynaptic spike broadening reduces junctional potential amplitude. Nature 340, 636-638.

Streit, J., and Lux, H. D. (1989). Distribution of calcium currents in sprouting PC12 cells. J. Neurosci. 9, 4190-4199.

Swartz, K. J., and Bcan, B. P. (1992). Inhibition of calcium channels in rat $\mathrm{CA} 3$ pyramidal neurons by a metabotropic glutamate receptor. J. Neurosci. 12, 4358-4371.

Thompson, S. M., and Gähwiler, B. H. (1992). Comparison of the actions of baclofen at pre- and postsynaptic receptors in the rat hippocampus in vitro. J. Physiol. 457, 329-345.

Thompson, S. M., Capogna, M., and Scanziani, M. (1993). Presynaptic inhibition in the hippocampus. Trends Neurosci. 16, 222227.

Travagli, R. A., Ulivi, M., and Wojcik, W. J. (1991). $\gamma$-Aminobutyric acid $B$ receptors inhibit glutamate release from cerebellar granule cells - consequences of inhibiting cyclic-AMP formation and calcium influx. J. Pharmacol. Exp. Ther. 258, 903-909.

Ui, M. (1984). Islet-activating protein, pertussis toxin: a probe for functions of the inhibitory guanine component of adenylate cyclase. Trends Pharmacol. Sci. 5, 277-279.

Yatani, A., Cudina, J., Brown, A. M., and Birnbaumer, L. (1987). Direct activation of mammalian atrial muscarinic potassium channels by GTP regulatory protein $G_{k}$. Science 235, 207-211.

Yoon, K. W., and Rothman, S. M. (1991). The modulation of rat hippocampal synaptic conductances by baclofen and $\gamma$-aminobutyric acid. J. Physiol. 442, 377-390. 